\title{
Long-term effect of soil management on the carbon-dioxide emission of the soil
}

\author{
JÓZSEF ZSEMBELI - GYÖRGYI KOVÁCS - KRISZTINA CZELLÉR - \\ GÉZA TUBA
}

University of Debrecen, ARIEF, Research Institute of Karcag, Karcag, Hungary zsembeli@agr.unideb.hu

\begin{abstract}
Summary
$\mathrm{CO}_{2}$ emission from soils is one of the most important elements of the global carbon cycle, thus it has crucial rule in climate change. Each soil cultivation operation intervenes in the microbiological life of the soil, hence tillage is a factor through that the processes taking place in soil can be controlled. During the last decades, the organic material content of agricultural soils decreased to the half due to the intensive management resulting in the degradation of natural soil fertility. While intensive, plough-based tillage can cause soil degradation and erosion, the physical, chemical and biological status of the soil can be significantly improved through the application of conservation tillage methods. The results of long-term experiments prove that soil protective tillage enhances the enrichment of organic matter in the top layer of the soil. In order to reveal the role of tillage systems in $\mathrm{CO}_{2}$ emission from the soil, regular measurements were carried out in the plots with conventional and reduced tillage of the soil cultivation experiment of Research Institute of Karcag. Anagas CD 98 and Gas Alert Micro 5w infrared gas analysers were used to measure $\mathrm{CO}_{2}$-concentrations, and a specially developed method (consisting of a frame and a bowl) was applied to delimitate the measuring area. Most of the measurements were done on stubbles after harvest in order to exclude root respiration. The weather conditions of the examined 10 years were very changeable providing a good chance to compare them to each other. We found the tillage operations resulting in higher emission values in both tillage systems. On stubbles higher and more even emission was characteristic to reduced tillage due to the lower degree of soil disturbance and higher soil moisture content.
\end{abstract}

Keywords: long-term experiment, soil cultivation, $\mathrm{CO}_{2}$ emission, stubble, microbiological activity

\section{Introduction}

$\mathrm{CO}_{2}$ emission from soils is one of the most important elements of the global carbon cycle, thus it has crucial rule in climate change. Each soil cultivation operation intervenes to the soil microbiological life hence tillage is a factor through that the processes taking place in soil can be controlled. During the last decades the organic material content of 
agricultural soils decreased to the half due to the intensive management resulting in the degradation of natural soil fertility. While intensive, plough-based tillage can cause soil degradation and erosion, the physical, chemical and biological status of the soil can be significantly improved by the application of conservation tillage methods. The results of long-term experiments prove that soil protective tillage enhances the enrichment of organic matter in the top layer of the soil.

International research results prove that the highest carbon-dioxide loss from the soil is due to the regular ploughing of the soil (Tracy et al., 1990; Giuffré et al., 2003). Land use under field conditions is sum of various crops with different biological needs and production technologies. Land use is the tool that can harmonize the agroecological conditions and growing technology (Birkás et al., 1999). Soil cultivation is an element of land use that can influence the biological activity of the soil.

Conventional tillage can contribute to climate changes. The regular turning of the soil by ploughs considerably increases the carbon-dioxide emission of croplands (Reicosky, 1995). Disturbing the soil by tillage results in looser soil structure, changing air regime, fast gas exchange.

The increased oxygen content of the soil induces intensive microbiological activity. The carbon-dioxide generated from the decomposition of organic materials is emitted into the atmosphere, consequently it can be one of the direct causes of the global climate change (Gyuricza et al., 2005). Since the increased microbiological activity is in conjunction with intensive organic material consumption, direct correlation can be observed among the aeration of the soil, the carbondioxide emission and the humus content (Szabó, 1986). The humus materials of the soil are generated along several decades or centuries therefore even a decrease of a few percentages can hardly be turned back.

By the application of good agricultural practice the carbon-dioxide fixing ability of the soil can be increased, the organic carbon loss can be reduced, and humification can be strengthened. All these result in the increase of the organic matter content of the soil (Németh, 2004; Koós and Németh, 2007).

Shallow soil cultivation with no turning results in lower aeration and drying therefore the microbiological activity is poorer, but longer lasting (Birkás, 1993), while the organic material content available for the microbes is higher in undisturbed soils (Tóth et al., 2009).

Zsuposné (2003) also carried out microbiological examinations in the log-term soil cultivation experiment at Karcag. By comparing the conventional and conservation tillage systems she established that there was no significant difference in the activity of certain enzymes (urease, catalase), while higher activity of phosphatase could be figured out in the 
case of conventional tillage. The annual average of carbon-dioxide production in conservation tillage system was $7.8 \%$ higher compared to the conventional one.

On the base of data originating from the examination of conventional and reduced tillage Zsembeli and Nagy (2004) established that higher carbon-dioxide emission to the air is characteristic to the plots of reduced tillage, although the differences are not considerably big every time. They figured out that root respiration has the major role in soil respiration; measured data proved that root respiration is the source of $70-80 \%$ of the total emitted carbon-dioxide in the case of an active, growing crop stand.

In this paper the results gained from the measurement on stubbles are published, as we consider stubbles the most suitable state when the effects of different soil cultivation systems on the microbiological activity of the soil can be compared. In stubble state, obviously after the harvest of the crop), root respiration is not characteristic, therefore the carbondioxide gas emitted from the soil is purely due to the microbiological activity, so more precise comparisons can be done.

\section{Material and methods}

The objective of the complex soil tillage experiment, launched in 1997, was to establish capabilities and effectiveness of a soil conservation tillage system, which stops the physical degradation the of soil among agro-ecological and arable ecosystems in the Trans-Tisza Region and to develop an environmental friendly energy-saving cultivation system. The long term cultivation experiment includes: reduction of the regularly cultivated layer, leaving the ploughing tillage method, application of reduced tillage and no tillage and direct seeding, application of mulching technology, and use of deep loosening to eliminate the physical defects of the soil and the factors limiting soil fertility. The total size of the plots of the experiment is 16 ha, the conventionally cultivated (plough based) plot was set on $3.5 \mathrm{ha}$, and the reduced tillage plot is 12.5 ha (Figure 1). Two plants were growing in crop rotation in the four plots. The plants (wheat, maize, peas, sunflower, and barley) represent the structure of crop production characteristic to Nagykunság region.

In order to reveal the role of tillage systems in $\mathrm{CO}_{2}$-emission from the soil, regular measurements were carried out in the plots with conventional and reduced tillage of the soil cultivation experiment.

Three similar infrared gas analysers (Figure 2) were used to measure CO2 concentrations: an Anagas CD 98 (2006-2010), a Gas Alert Micro 5w (2011-2015), and a Testo 535 (2016-). A specially developed measuring set consisting of a frame and a bowl was applied to delimitate the measuring area. The volume of the plastic bowl is $2800 \mathrm{~cm}^{3}$, the diameter 
of the metal frame is $20 \mathrm{~cm}$. In order to have perfect isolation, the metal frame is inserted into the soil (sharpened bottom edge) down to $5.5 \mathrm{~cm}$ and the trough around the frame is filled with water. This set was developed by the authors in 2005, as it was realised it is more practical and suitable for $\mathrm{CO}_{2}$-emission measurements on stubbles and can substitute the cylinder method that was used earlier (Zsembeli et al., 2005). To determine the actual soil moisture contents and temperature TTN-M type probes were used.

Figure 1. The soil cultivation experiment at Karcag

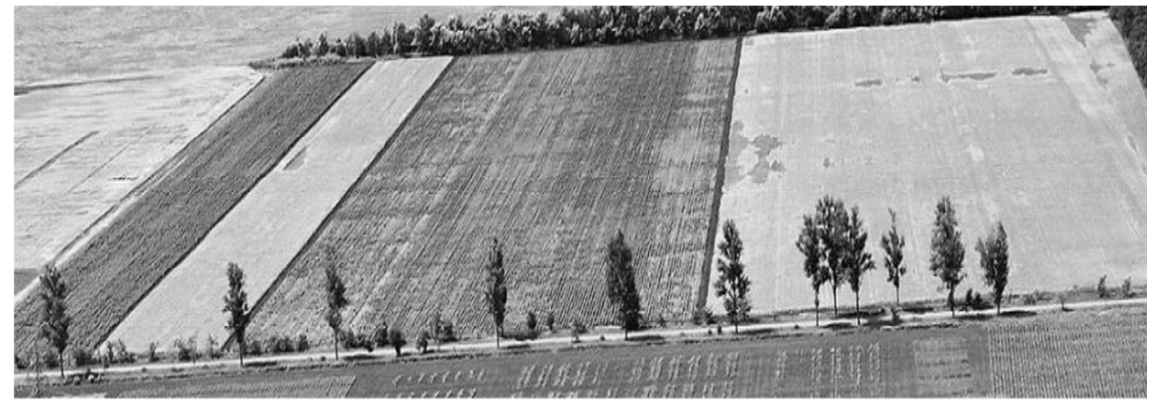

Figure 2. The frame+bowl method with the gas analysers (Anagas CD 98, Gas Alert Micro 5w and Testo 535)
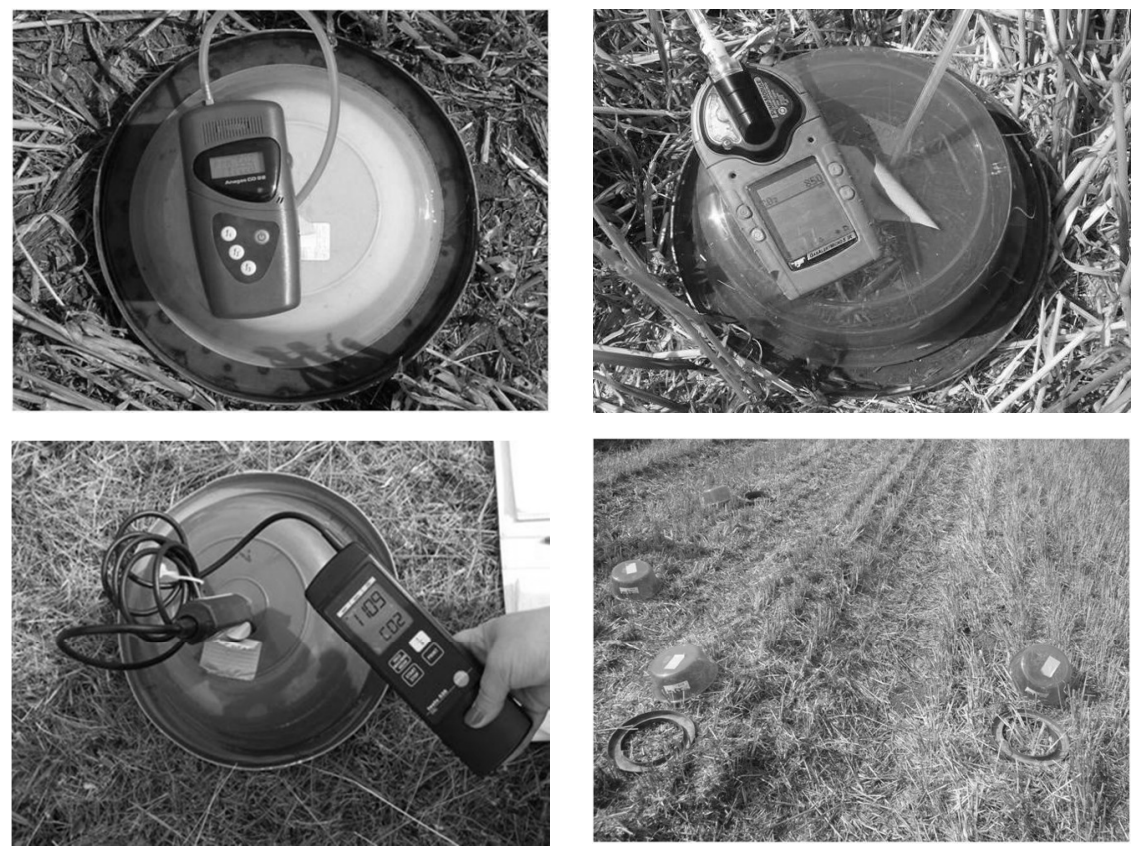
To calculate the $\mathrm{CO}_{2}$-emission from soil the following formula was used:

$$
\mathrm{F}=\mathrm{d} *(\mathrm{~V} / \mathrm{A}) *(\mathrm{C} 2-\mathrm{C} 1) / \mathrm{t} * 273 /(273+\mathrm{T})
$$

where F: $\mathrm{CO}_{2}$ flux $\left(\mathrm{g} \mathrm{m}^{-2} \mathrm{~h}^{-1}\right)$, d: density of $\mathrm{CO}_{2}\left(\mathrm{~kg} \mathrm{~m}^{-3}, 1.96\right.$ for $\left.\mathrm{CO}_{2}\right), \mathrm{V}$ : volume of head space of chamber $\left(\mathrm{m}^{3}\right) \mathrm{A}$ : area of chamber $\left(\mathrm{m}^{2}\right), \mathrm{C} 1: \mathrm{CO}_{2}$ concentration at time of start $\left(\mathrm{m}^{3} \mathrm{~m}^{-3}\right), \mathrm{C} 2: \mathrm{CO}_{2}$ concentration at time of end $\left(\mathrm{m}^{3} \mathrm{~m}^{-3}\right)$, t: duration of measurement $(\mathrm{s}), \mathrm{T}$ : air temperature $\left(\mathrm{C}^{\circ}\right)$.

Most of the measurements were done on stubbles after harvest in order to exclude root respiration that can be $80 \%$ of the total emission. The weather conditions of the examined 10 years were very changeable providing a good chance to compare them.

Parallel to the carbon-dioxide concentration measurements samples from the upper $10 \mathrm{~cm}$ deep soil layer, which has the major role in soil respiration, were taken in order to determine the actual soil moisture contents by gravimetric method.

\section{Results and discussion}

In the investigated ten years the weather was very diverse so it created an excellent opportunity for comparison between years. Figures 3-12 show the $\mathrm{CO}_{2}$-emission data calculated from the $\mathrm{CO}_{2}$-concentration measurements in the two cultivation systems.

The results gained from the soil cultivation experiment must be evaluated separately for each year as the weather, agrotechnical and soil status conditions were considerably different each crop year. Each measurement were done in at least three replications, the averages of the replications are illustrated in the figures. The weather conditions of the investigated ten years were very variable providing excellent opportunity to compare the years.

The data of $25^{\text {th }}$ July, 2006 were measured on stubbles after harvest (Figure 3), significant difference could be figured out between conventional and reduced tillage in terms of carbon-dioxide emission: 0.304 and $0.463 \mathrm{~g} \mathrm{~m}^{-2} \mathrm{~h}^{-1}$ were measured under similar soil moisture conditions (18 and $19 \mathrm{~m} / \mathrm{m} \%$, respectively).

Oilseed rape was the indicator crop in 2007; it was harvested on $21^{\text {st }}$ June. The measurements were done 4 days after the harvest on stubble (Figure 4). Higher carbon-dioxide emission values were calculated (the mean value was $\left.0.333 \mathrm{~g} \mathrm{~m}^{-2} \mathrm{~h}^{-1}\right)$ for conventional tillage, while significantly much lower $\left(0.158 \mathrm{~g} \mathrm{~m}^{-2} \mathrm{~h}^{-1}\right)$ mean value was characteristic to the plot of reduced tillage. The crop year of 2007 can be considered extreme from several points of view: very high annual mean air temperature $\left(12.0{ }^{\circ} \mathrm{C}\right)$ and extremely high maximum value of soil 
temperature $\left(31.4{ }^{\circ} \mathrm{C}\right.$ measured at the depth of $\left.10 \mathrm{~cm}\right)$ were characteristic to that year. These extremely high temperature values, together with the dry soil status, were not favourable for the microbiological activity of the soil. Root analyses showed deeper roots of higher mass in the soil of the conventional tillage plot providing more organic matter as the source of carbon-dioxide emission.

Figure 3. $\mathrm{CO}_{2}$ emission on wheat stubble, 2006

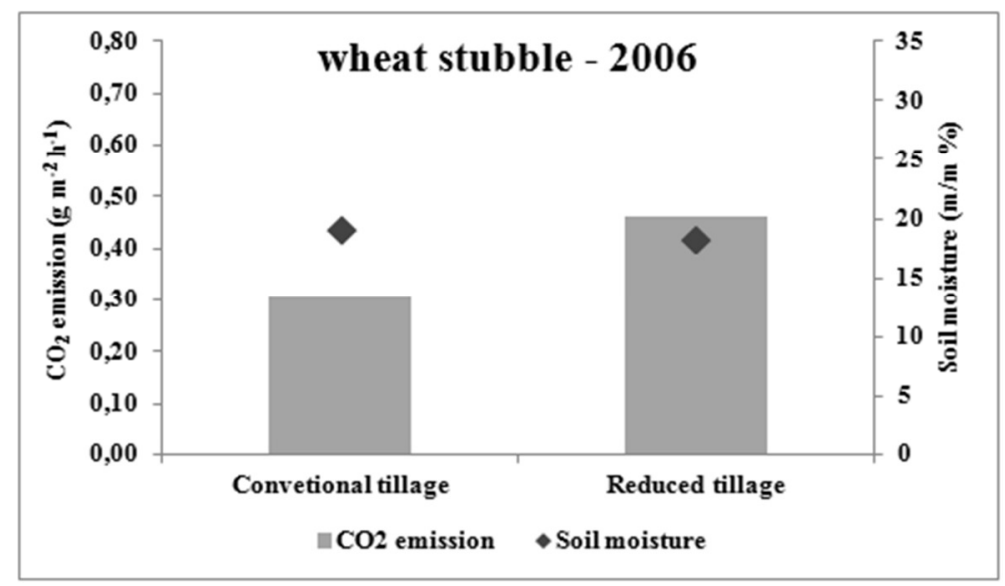

Figure 4. $\mathrm{CO}_{2}$ emission on rape stubble, 2007

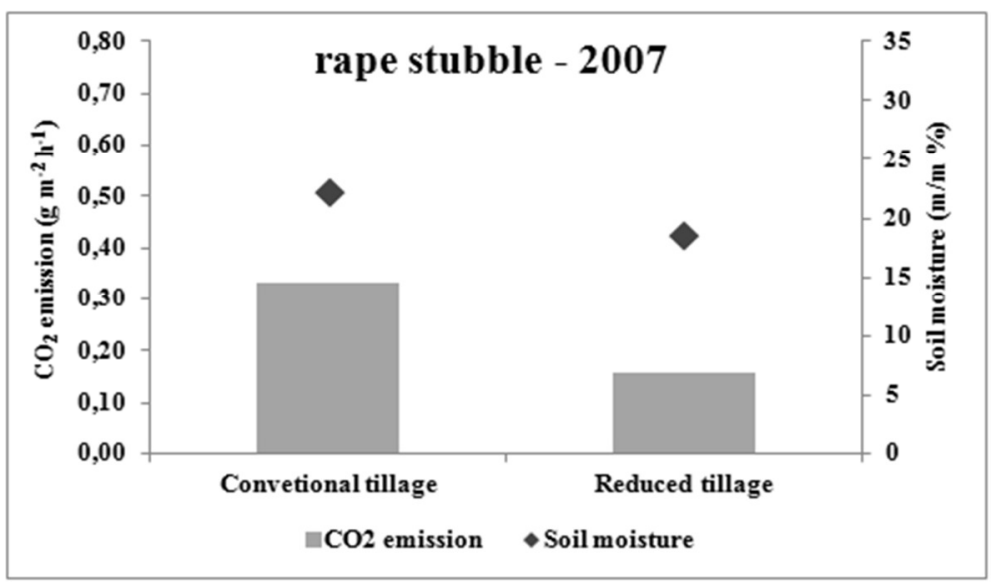

In 2008 the measurements were done on $24^{\text {th }}$ June, after the harvest of winter barley. The soil moisture content at the date of the measurement was close to the value of field capacity. Under these conditions we determined higher carbon-dioxide emission $\left(0.614 \mathrm{~g} \mathrm{~m}^{-2} \mathrm{~h}^{-1}\right)$ in the case of 
reduced tillage compared to the conventional one with its $0.522 \mathrm{~g} \mathrm{~m}^{-2} \mathrm{~h}^{-1}$ mean value (Figure 5).

In 2009 the measurements carried out after the harvest of winter wheat showed significantly higher carbon-dioxide emission in the soil of the reduced tillage plot compared to conventional tillage ( 0.73 and $0.31 \mathrm{~g}$ $\mathrm{m}^{-2} \mathrm{~h}^{-1}$, respectively) due to the higher soil moisture content and organic matter input characterising the reduced tillage system (Figure 6).

Figure 5. $\mathrm{CO}_{2}$ emission on barley stubble, 2008

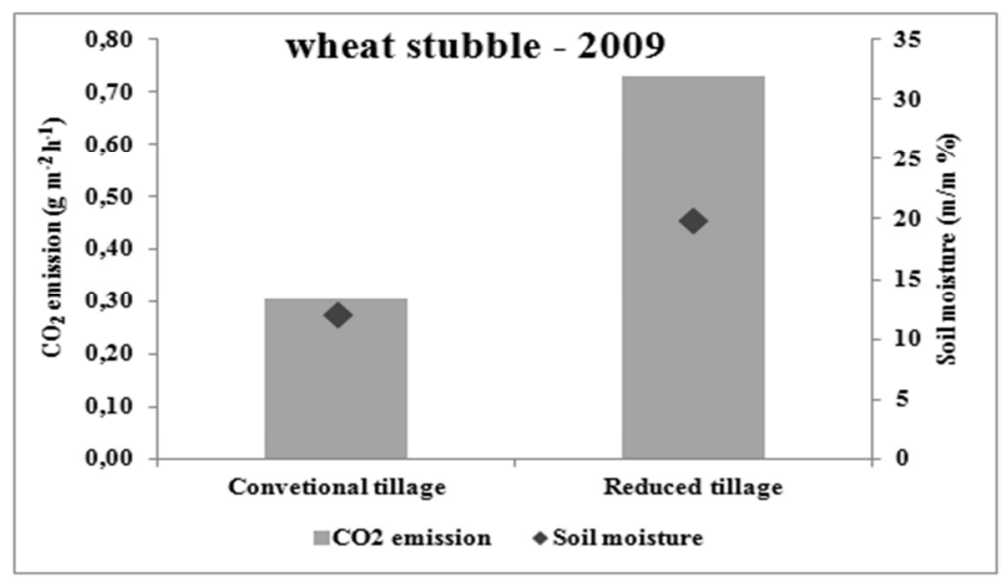

Figure 6. $\mathrm{CO}_{2}$ emission on wheat stubble, 2009

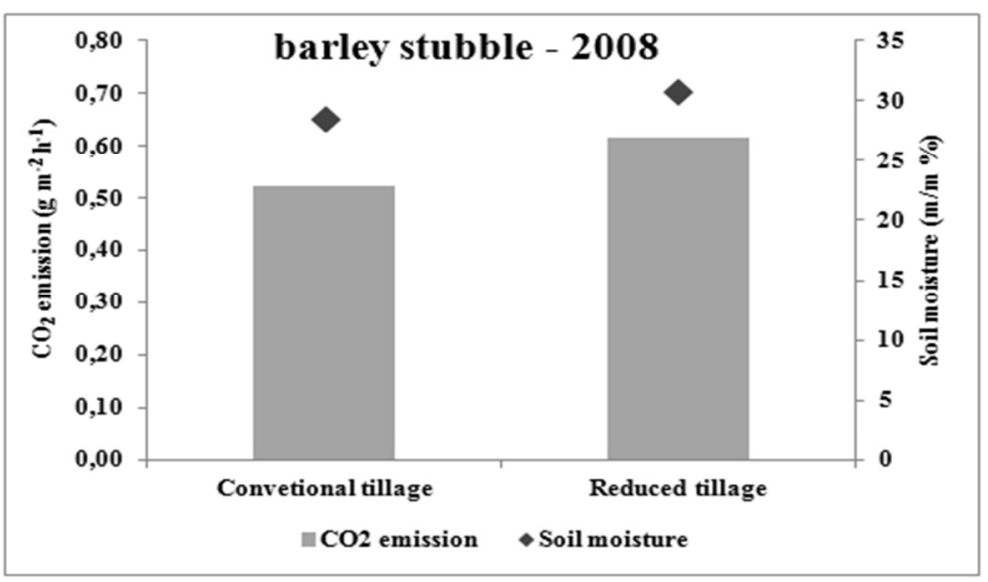

In 2011 slightly higher values of carbon-dioxide emission was characteristic for reduced tillage $\left(0.191 \mathrm{~g} \mathrm{~m}^{-2} \mathrm{~h}^{-1}\right)$ determined in 
September after the harvest of sunflower. We calculated $0.143 \mathrm{~g} \mathrm{~m}^{-2} \mathrm{~h}^{-1}$ as a mean value for conventional tillage (Figure 7).

Extreme weather conditions characterized the year of 2012; but the plots of reduced tillage still showed higher carbon-dioxide emission on winter barley stubble (Figure 8). The mean values were $0.375 \mathrm{~g} \mathrm{~m}^{-2} \mathrm{~h}^{-1}$ and $0.250 \mathrm{~g} \mathrm{~m}^{-2} \mathrm{~h}^{-1}$, respectively.

Figure 7. $\mathrm{CO}_{2}$ emission on sunflower stubble, 2011

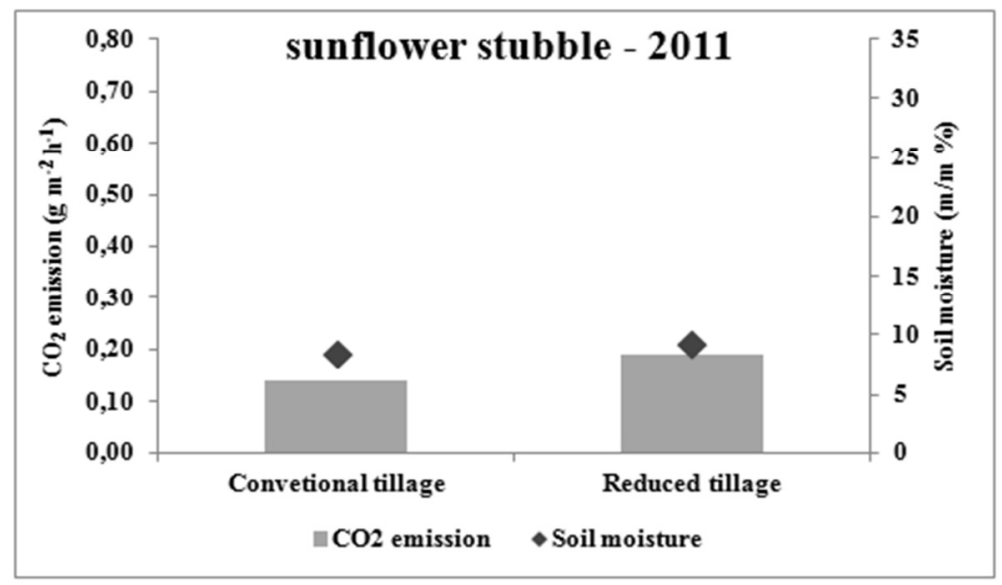

Figure 8. $\mathrm{CO}_{2}$ emission on barley stubble, 2012

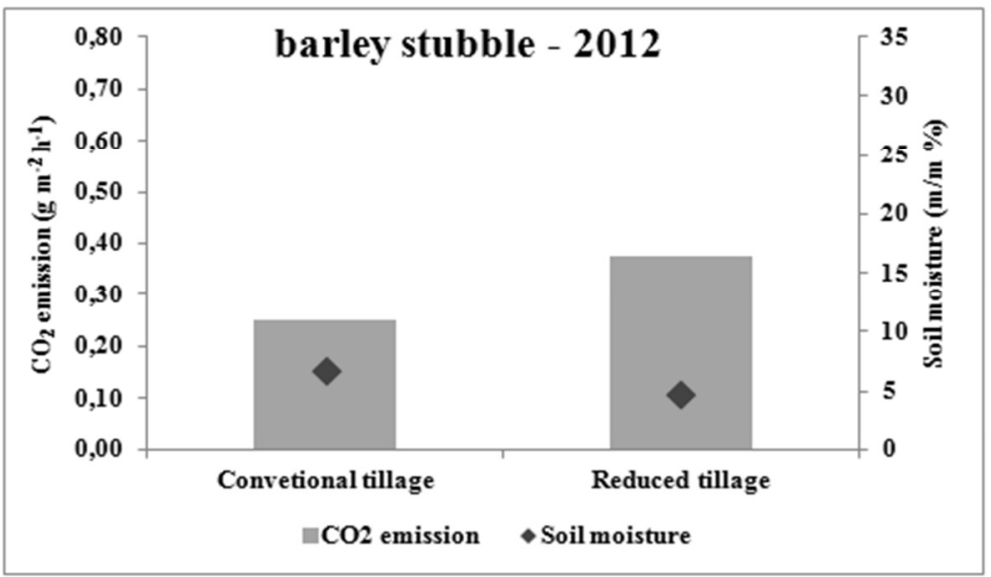

Winter fodder pea was the indicator crop in the soil cultivation experiment in 2013. Contrary to the previous years, the measurements carried out after the harvest showed higher carbon-dioxide emission 
(Figure 9) from the conventional tillage (0.604 $\left.\mathrm{g} \mathrm{m}^{-2} \mathrm{~h}^{-1}\right)$ compared to reduced tillage $\left(0.489 \mathrm{~g} \mathrm{~m}^{-2} \mathrm{~h}-1\right)$. We could not determine any reasons that led to this difference.

In 2014 winter barley was harvested from the plots of the soil cultivation experiment. The measurements were carried out on stubbles that year too (Figure 10), higher values of carbon-dioxide emission were found in the case of reduced tillage $\left(0.246 \mathrm{~g} \mathrm{~m}^{-2} \mathrm{~h}^{-1}\right)$, but not significantly lower values were determined for conventional tillage $\left(0.180 \mathrm{~g} \mathrm{~m}^{-2} \mathrm{~h}^{-1}\right)$.

Figure 9. $\mathrm{CO}_{2}$ emission on pea stubble, 2013

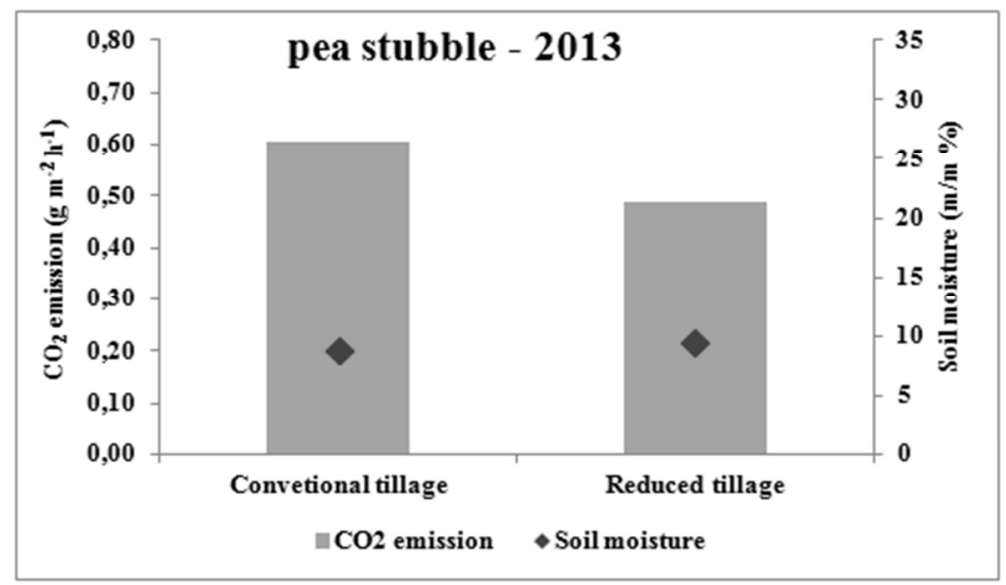

Figure 10. $\mathrm{CO}_{2}$ emission on barley stubble, 2014

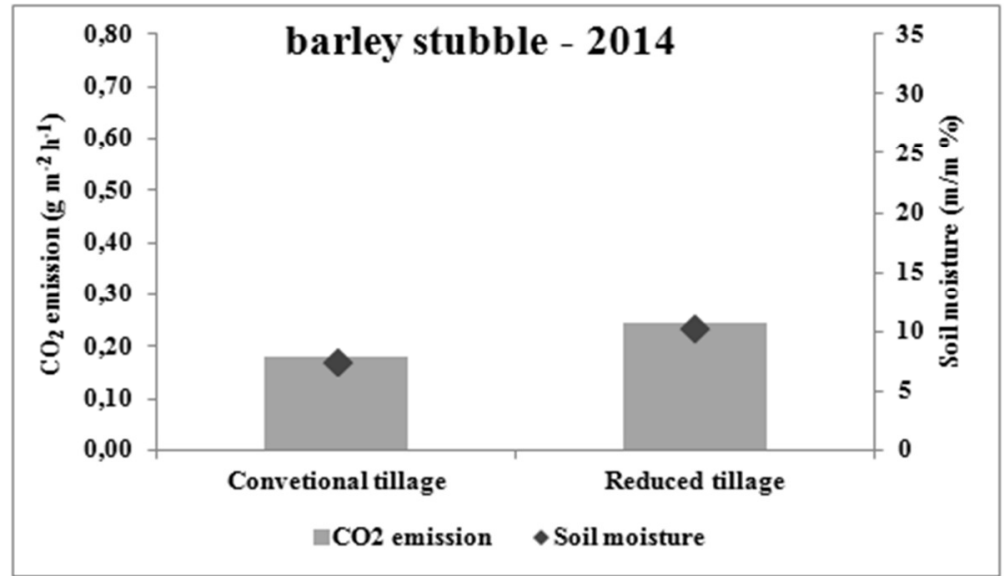


2015 was a droughty year, low carbon-dioxide values were characteristic due to the extensive microbiological activity of the soil (Figure 11). In such very dry conditions the effect of soil cultivation is not so expressive as soil moisture is a limiting factor for soil respiration. Similar values were characteristic for both tillage systems; we measured $0.202 \mathrm{~g} \mathrm{~m}^{-2} \mathrm{~h}^{-1}$ and $0.204 \mathrm{~g} \mathrm{~m}^{-2} \mathrm{~h}^{-1}$ on winter fodder pea stubbles.

In 2016, after the harvest of winter wheat, we measured low values for both treatments, but slightly higher values in the case of reduced tillage $\left(0.281 \mathrm{~g} \mathrm{~m}^{-2} \mathrm{~h}^{-1}\right)$, while $0.239 \mathrm{~g} \mathrm{~m}^{-2} \mathrm{~h}^{-1}$ carbon-dioxide emission was calculated for conventional tillage (Figure 12).

Figure 11. $\mathrm{CO}_{2}$ emission on pea stubble, 2015

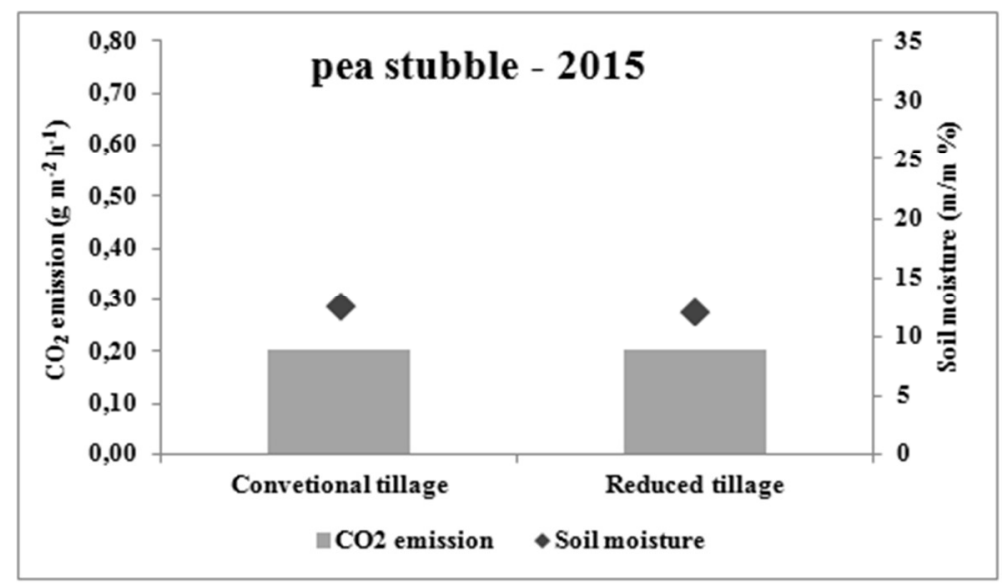

Figure 12. $\mathrm{CO}_{2}$ emission on barley stubble, 2016

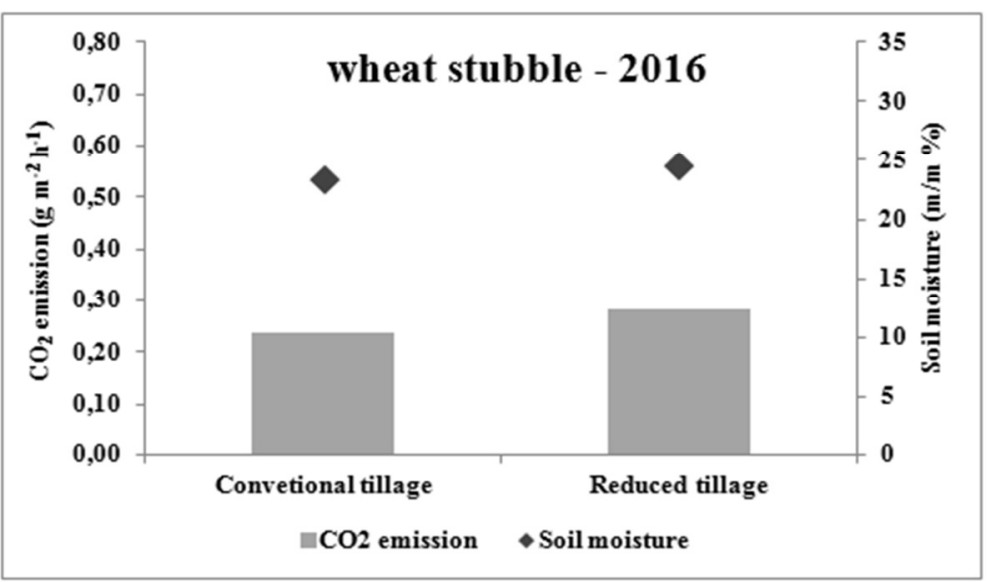


Table 1 contains the data of the statistical analysis of the carbondioxide emission values determined during the ten years of the investigation. The mean value of reduced tillage is higher, though the standard deviation is also high in that case. The minimum values are quite close to each other (0.143 and 0.158$)$, the maximum value is much higher in the case of reduced tillage (0.730) compared to conventional tillage (0.604).

The $\mathrm{CO}_{2}$ emissions of the soil are close correlation with the increasing soil moisture content. Hence environmental conditions (soil moisture content, temperature, $\mathrm{pH}$, etc.) decisively influence the change of soil organic matter (accumulation or reduction) and the living conditions of the soil micro-organisms.

Higher emission values were characteristic on the stubble on the plot without disturbance in most cases. This proves that better conditions formed in the soil of reduced cultivation plot to the microbial processes. Based on the obtained results, direct correlation can be observed between the intensity of tillage and carbon dioxide emissions.

There is close correlation between the degree and intensity of $\mathrm{CO}_{2}-$ emission from the soil and the structural state and organic matter content of the soil. Applying alternative soil cultivation methods based on reduced disturbance of the soil more favourable conditions can be created in order to increase the organic matter content of the soil and the availability of the nutrients for the crops.

Table 1. Descriptive statistics of the $\mathrm{CO}_{2}$ emission values

\begin{tabular}{lcc}
\hline \multicolumn{1}{c}{$\mathrm{CO}_{2}$ emission $\left(\mathrm{g} \mathrm{m}^{-2} \mathrm{~h}^{-1}\right)$} & Conventional tillage & Reduced tillage \\
\hline Mean & 0.308 & 0.375 \\
Standard error & 0.047 & 0.061 \\
Median & 0.277 & 0.328 \\
Standard deviation & 0.148 & 0.194 \\
Sample variance & 0.022 & 0.038 \\
Kurtosis & 0.623 & -0.669 \\
Skewness & 1.167 & 0.682 \\
Range & 0.461 & 0.572 \\
Minimum & 0.143 & 0.158 \\
Maximum & 0.604 & 0.730 \\
Confidence level $(95.0 \%)$ & 0.106 & 0.139 \\
\hline
\end{tabular}

\section{Conclusions}

Assessing all our data it can be concluded that reduced tillage showed higher carbon-dioxide emission values each of the 6 years when winter cereals (wheat, barley) were the indicator crops, the differences were significant in two years (2006 and 2009). 
Only in one year out of ten was sunflower the indicator crop, in that case we could not figure out considerable difference between the two investigated soil tillage systems regarding the carbon-dioxide emission from the soil.

There were two years when the stubble of winter pea could be studied: in one of the two years no difference could be figured out, while in the other year the conventional tillage resulted in higher carbondioxide emission. Since fodder pea needs deeper cultivation of the soil, conventional tillage, where ploughing down to $30 \mathrm{~cm}$ was carried out, was more satisfactory to that indicator crop.

Oilseed rape was examined in one year: also conventional tillage with its deeper root zone resulted in higher carbon-dioxide emission from the soil.

As a summary it can be concluded that in seven years out of ten reduced tillage resulted in higher carbon-dioxide emission from the soil. We proved with field measurements that due to the moderate soil disturbance and the favourable soil conditions for microbial activity, reduced tillage system resulted higher $\mathrm{CO}_{2}$-emission compared to the conventional tillage, though the emission was more balanced in time.

The application of reduced cultivation supported the soil in approaching its natural equilibrium state that manifested in the investigated factors of the soil carbon cycle. Under favourable soil moisture conditions microbiological activity (indicated by the level of $\mathrm{CO}_{2}$-emission) was increased where reduced tillage system was applied.

Analysing the amount and fractional composition of the soil organic matters we found that reduced tillage produced an increased ratio of the stabile humic materials that bound to the soil minerals taking part in the formation of a more favourable soil structure. These data can characterise the resilience of ecosystems of arable lands.

There are several methods to measure the $\mathrm{CO}_{2}$-emission of the soil, but none of them is universal, and can be used in any circumstances. The most problematic part is the spatial delimitation of the measurement area as the surface of the soil can be very various and proper isolation is a must. The tools (the infrared gas analysers and the frame+bowl set) we used for the in situ measurement were found effective and handy and recommended to be used to gain more information on the dynamics of $\mathrm{CO}_{2}$-emission from the soil.

Studying the effect of different soil utilisation/cultivation methods on the $\mathrm{CO}_{2}$ emission from soil is indisputably actual and needs more efforts as it can contribute to develop a more environmental friendly agricultural production. 


\section{References}

Birkás M.-Krisztián J.-Nagy J. (1999): Talajhasználat és talajvédelem. [In: Ruzsányi L.-Pepó P. (szerk.) Magyarország az ezredfordulón - Startégiai Kutatások az MTA-n.] Növényterm. Tud. Nap. 1999. január 26. Növénytermesztés és környezetvédelem MTA Agr. Tud. Oszt. Budapest. 19-29.

Birkás M. (1993): Talajmúvelés. [In: Nyiri L. (szerk.) Földmúveléstan.] Mezőgazda Kiadó. Budapest. 96-194.

Giuffré, L.-Heredia, O.-Pascale, C.-Cosentino, D.-Conti, M.-Schnug, E. (2003): Land use and carbon sequestration in arid soils of northern Patagonia (Argentina). Landbauforschung Völkenrode. 53: 13-18.

Gyuricza, Cs.-Földesi, P.-Mikó, P.-Ujj A. (2005): Carbon dioxide emission from arable lands. Cereal Res. Commun. 33. 1: 89-92.

Koós, S.-Németh, T. (2007): Relation between carbon-dioxide fluxes and nitrogen content of soil in a long-term fertilization experiment. Cereal Res. Commun. 35. 2: 641-644.

Németh, T. (2004): Organic matter cycles in agriculture. [In: Láng I. et al. (eds.) Pollution process in agri-environment.]

Reicosky, D. C. (1995): Impact of tillage on soil as a carbon sink. Farming for a better environment. A White Paper. Soil, Water Conservation Soc. Ankeny. Iowa. 67.

Szabó I. M. (1986): Az általános talajtan biológiai alapjai. Mezőgazdasági Kiadó. Budapest.

Tóth, E.-Koós, S.-Farkas, Cs. (2009): Soil carbon dioxide efflux determined from large undisturbed soil cores collected in different soil management systems. Biologia. 64. 3: 643-647.

Tracy, P.-Westfall, D. G.-Elliott, E. T.-Peterson, G. A.-Cole, C. V. (1990): Carbon, nitrogen, phosphorus, and sulfur mineralization in plow and no-till cultivation. Soil Sci. Soc. Am. J. 54: 457-461.

Zsembeli J.-Nagy I. (2004): Talajmúvelési technológiák hatása a széndioxid emisszióra. 4. Alföldi Tudományos Tájgazdálkodási Napok. Tessedik Sámuel Főiskola Mezőgazdasági Főiskolai Kar. Paper 41.

Zsembeli, J.-Tuba, G.-Juhász, Cs.-Nagy, I. (2005): $\mathrm{CO}_{2}$-measurements in a soil tillage experiment. Cereal Res. Commun. 33. 1: 137-140.

Zsuposné Oláh Á. (2003): Talajt javító és kímélő technológiák talajbiológiai tesztelése. Talajjavítás-talajvédelem. Debrecen. 63-70. 